\title{
The Present, the Past and the Material Object
}

Paul Eggert

peggert@luc.edu

Follow this and additional works at: https://ecommons.luc.edu/english_facpubs

Part of the English Language and Literature Commons

\section{Author Manuscript}

This is a pre-publication author manuscript of the final, published article.

\section{Recommended Citation}

'The Present, the Past and the Material Object'. In The Explicit Material: Inquiries on the Intersection of Curatorial and Conservation Cultures. Ed. Hanna Hölling, Francesca Bewer, Katarina Ammann (Leiden, Netherlands: Brill, 2019)

This Book Chapter is brought to you for free and open access by the Faculty Publications and Other Works by Department at Loyola eCommons. It has been accepted for inclusion in English: Faculty Publications and Other Works by an authorized administrator of Loyola eCommons. For more information, please contact ecommons@luc.edu.

\section{(c) $($ () $\ominus$}

This work is licensed under a Creative Commons Attribution-Noncommercial-No Derivative Works 3.0 License. (c) BRILL 2019 
The Present, the Past and the Material Object

\section{Paul Eggert \\ Loyola University Chicago}

NOTE: This is a preprint version, before final corrections and revisions, of a chapter in The Explicit Material: Inquiries on the Intersection of Curatorial and Conservation Cultures, ed. Hanna Hölling, Francesca Bewer, Katarina Ammann in a Brill series Studies in Art \& Materiality, series editor: AnnSophie Lehmann (Leiden, Netherlands: Brill, 2019). For quotation purposes the published version should be used.

\section{ABSTRACT}

Before Thomas Hardy rose to fame as the author of Tess of the D'Urbervilles and then later as a poet, he had pursued a professional career as an architect and, for a time, as a restorer of medieval church buildings. When he could afford to do so he gave up his professional life for writing, but an abiding attitude toward the past and its material manifestations links the two phases of his life. In his literary works he frequently returned to the possibility of recovering the past, to the conditions of that recovery and thus to the nature of its ongoing life in the present. For him, the ancient natural landscape and the historic built environment served as vital links.

This essay starts with discussion of a poem of Hardy's that serves as the spur for a meditation on the general conditions of our intercourse with the past, especially as engaged by its material forms, whether in buildings or art works or literary works. Distinctions between the forms are of course necessary but, it is argued, continuities remain: the mute testimony of the material object concerning the agents of its creation; the role of the viewer or reader in realising the work; the hand of the editor-conservator; and the role of time in its successive forms of existence.

$\mathrm{BIO}$

Paul Eggert (pauleggert7@gmail.com) is an editorial theorist, scholarly editor and book historian. He holds the Martin J. Svaglic Endowed Chair in Textual Studies at Loyola University Chicago.

In his book Securing the Past: Conservation in Art, Architecture and Literature Eggert extended the purview of editorial theory to encompass the different but, as it turned out, parallel discourses surrounding the conservation of historic buildings and art works, and the nature of forgery. The book was published by Cambridge University Press in England in 2009; it won the Society for Textual Scholarship's Finneran Award as the best book of editorial theory for 2009-10.

His later thinking about the empirical realities of the textual condition may be found in his Biography of a Book (Pennsylvania State University Press and Sydney University Press, 2013) and 


\section{p. 2}

The Work and the Reader in Literary Studies: Scholarly Editions and Book History (Cambridge: Cambridge University Press, 2019).

Over the years, full-scale scholarly editions of works by D. H. Lawrence, Henry Kingsley, Rolf Boldrewood, Henry Lawson and Joseph Conrad have appeared under his hand.

A fellow of the Australian Academy of the Humanities since 1998, Eggert served as the general editor of its Academy Editions of Australian Literature (10 vols, 1996-2007) and received the Centenary Medal of the Commonwealth of Australia for services to the study of literature in 2003. 
The Present, the Past and the Material Object

To edit is to present, to make the text of a work present for readers. Something so simple in principle ought to be straightforward in practice, but it is not. A partially documented past and the variousness of the present are tricky to keep in a sensible relation to one another. This is true as much for conservators of art objects and historic buildings as it is for scholarly editors of literary works and musicologists editing musical scores. It is a matter of articulating, before one can begin sensibly to balance, the competing demands of the past and the present in the moment that the editor or conservator intervenes between them.

The following poem nicely localises the general problem. Published in 1902 in a volume entitled Poems of the Past and the Present, 'The Self Unseeing' is deceptively simple. It was written by a man in his early sixties, Thomas Hardy, famously the author of the novel Tess of the D'Urbervilles. The poem is about returning to his childhood home, a large thatched cottage at Higher Bockhampton in Dorset in the southwest of England. Hardy's father had been a successful builder locally; but, as he worked with his hands, he could not be considered a gentleman. Hardy's mother was determined the son would do better. So, in due course, the young Hardy became an architect and worked in London; as a professional, he rose in the world. This younger Hardy, the architect, specialised for a time in the restoration of medieval churches. The later and much better known Hardy - the novelist and poet - ceaselessly returned in imagination and spirit to the scenes of his childhood and young manhood. He breathed deeply of the air of the past. He was at his most alive there. But he refused the tempting consolations of nostalgia and sentimentality as a delusion.

This refusal of easy familiarity is evident in the poem. Its attempt to bring the past into the present is riddled with paradox, even though at first reading the situation seems simpler than that:

The Self-Unseeing

Here is the ancient floor,

Footworn and hollowed and thin,

Here was the former door

Where the dead feet walked in.

She sat here in her chair,

Smiling into the fire;

He who played stood there,

Bowing it higher and higher. 


\author{
Childlike, I danced in a dream; \\ Blessings emblazoned that day; \\ Everything glowed with a dream; \\ Yet we were looking away! ${ }^{1}$
}

The sense of place is wonderfully firm. It is registered with the firm trochaic beat on the opening word 'Here' - 'Here is the ancient floor' - a confident note repeated at the beginning of the third line. Security of place in the old family home prompts the experience of the past. But time is nowhere near as obliging as place. Rather, it shifts, extends, withdraws, as the gaze of the visitorpoet to his old home wanders across the scene, which becomes both present and past simultaneously. There is, there can be, the poem seems to say, no clear temporal differentiation since the past is only available in the present.

The quandary is apparent in the very first line where we read that ancientness ' is!. 'Here is the ancient floor'. This is odd. The floor that is 'footworn and hollowed and thin' is in that condition in the poem's present. On the other hand, the door is now a 'former door', but is it formerness in the present or in the past? Chronology half falls into place, but not quite, when, in the following line, it is troubled by this dislocating locution: 'Here was the former door/ Where the dead feet walked in'. It is a chastening, sobering, almost horrible thought. They were not dead as they walked in, but yet they are now; and the metonymy (feet standing in for people) is dehumanising, suggesting that a stoic refusal of connection to the dead is happening here. Coarsening the expression in this way evidently helps the poet, in the act of writing, to steady himself so as to keep at bay an unbidden wave of sentimentality that might otherwise cloud his vision.

Despite this instinctive precaution the emotionally irruptive threat of the past remains in place, and the present courts its return. As we soon see in the next stanza, defended against or not, the past will not be walled in, even if entry to it has to be earned. In this second stanza, we are granted the simplicity of the ordinary past tense, with the domestic scene of memory now uncomplicatedly in the past. It is a welcome and touching release after the sombreness of the first stanza:

She sat here in her chair,

Smiling into the fire;

He who played stood there,

Bowing it higher and higher.

1 Hynes 1982, vol. 1, 206. The original publication was in Hardy 1902. 
Hardy's father, in fact, was an amateur musician. He played at weddings and harvest festivals as part of a village group in a still essentially pre-industrial Dorset to which the modernising railway system had not reached until Hardy, who was born in 1840, turned seven. Hardy's own roots were firmly in that past. He returned repeatedly to it for the subject matter of his novels and poems. When he gave up architecture in London and returned to live in Dorset he took up his abode in a modern house that he had designed himself: this one had plans and was of the Victorian present. ${ }^{2}$ It served as his staging post for his forays into the past of Wessex, the locale he invented and gradually elaborated in his novels based on Dorset and its surrounding counties.

Hardy had already begun cultivating antiquarian interests, reading Hutchins's History and Antiquities of the County of Dorset in the late 1870s. When he moved back to Dorset permanently in 1883 he joined the local antiquarian club, served on the governing board of the Dorset County Museum and read systematically through the Dorset County Chronicle, starting at 1826 . Then, in autumn 1888, he undertook a walking tour exploring the countryside where Tess of the D'Urbervilles would be set.

For that novel, surface detail and local colour would have sufficed for his urban readers but Hardy had too great a respect for the truth and its disconcerting paradoxes to take the short cut. He knew well that the old way of rural living was fast slipping away but, doggedly, Hardy would not give in to the allure of nostalgia, to merely subjective yearnings for that past, or to a watery Romanticism about the beauties of a capital $N$ Nature in Dorset.

In his living and in his imagination he was obliged to shuttle continually between a stillpotent past and the unignorable present. As a young architect responsible for making decisions about the repair and restoration of medieval church buildings, he would have had in mind the selfconscious historicising that such influential figures as Pugin, Scott, Butterfield and Street imposed in England, and Viollet-le-duc in France. ${ }^{3}$ But Hardy was sceptical of its benefits and in later years would become scathing of its effects. He must have lived the modern quandary of the simultaneous retrievability and irretrievability of the past, one that extends down to us today. The poem is just a case in small of the general condition to which he was acutely sensitised.

Despite its blessed simplicity the poem reveals some sophisticated lessons. The already noted use of the simple past tense in the second stanza is complicated in its second and fourth

\footnotetext{
2 For biographical matters, see Millgate 2004. For his interest in restoration see Hardy 1906, Hardy 1927 and Hardy 1962, 76-79.

3 Architects George Gilbert Scott (1811-1878), Augustus W. N. Pugin (1812-1852), William Butterfield (1814-1900) and George Edmund Street (1824-1881). Pugin was the chief theorist of the Gothic Revival, in England, especially in his Contrast. Or, a parallel between the noble edifices of the fourteenth and fifteenth centuries and similar buildings of the present day, shewing the present decay of taste (1836) and An apology for the revival of christian architecture in England (1843). Eugène-Emmanuel Viollet-le-Duc (1814-1879) wrote the encyclopedic Dictionnaire raisonné de I'architecture francaise du Xle au XVle siècle. It appeared in ten volumes (1854-1868).
} 
lines by the use of verbs in the present-continuous tense - 'Smiling', 'Bowing' - which refuse to remain in the past. At first they seem to reach forward into the present of observation, out of the past: but that illusion of their continuing presence, or present-ness, cannot survive as the last stanza pulls back from the intense recollection of that scene. It retreats to a more generalising description where the past is, reluctantly, put back in its bottle:

Childlike, I danced in a dream;

Blessings emblazoned that day;

Everything glowed with a gleam;

Yet we were looking away!

The distinct end-of-line pauses enacted through their semicolons counteract the potential for a comforting scene, a consoling flow of recollection, giving us instead a series of sensitised yet almost staccato realisations.

The poem's conclusion, 'Yet we were looking away!', marks a sobering retreat into reflection in the present. But the awareness itself, although of the present, is paradoxically about an entrapment in the past. Then, in the past, one could have the moment but could not know its meaning; now, in the present, one can know the meaning but cannot have the moment. It is a double helix of choice, like a flypaper on which we are stuck and cannot break free.

The past refuses to remain there. It haunts a present that cannot help but gravitate towards it. This is all within the force-field of the human where pure subjectivity is not good enough, but pure objectivity is not available. We are implicated in the past; it is implicated in us, now.

That, I take it, is what the poem, at its most general, is saying. At the end of the day it is the object or the building or perhaps the landscape, which carries one back. In other words, materiality - materiality construed in its widest sense - is the lifeline of the past. But it requires agency human agency - to activate it. There are ways, and ways, of doing it. There are traps for young players. The mute testimony of objects can be redeemed by our mode of address to them. At its best, conservation is one of those modes. None of them is straightforward or unproblematic.

Normally we assume that a poem, as an intangible work, may simultaneously take variant forms - versions - without affecting its identity. In fact, this one was originally called in manuscript 'Unregarding' before Hardy changed the title so felicitously, alliteratively and purposefully to 'The Self-Unseeing'. In contrast, and again traditionally at least, we tend to think that tangible art works or buildings have a fixed physical identity, that the work is the object. As an architect and church restorer faced with the realities of buildings' decay, Hardy knew that their identity was not stable. Similarly, in the poem, he cannot help registering the fact, as he returns to his childhood home, that a door, once in this position, has since been filled in. As Stewart Brand has eloquently reminded us, no house remains the same. All long-lived buildings yield to the comfort and 
necessities of their inhabitants. All architectural forms, especially folk forms, are in a slow process of change. ${ }^{4}$ Important public buildings decay, are repaired or not; a fortunate few are restored or adapted to new uses. Paintings darken with age, are damaged, remounted, repaired. Their earlier versions may be revealed by $\mathrm{X}$-radiography and other techniques. Their identity is thus never fixed, just as Hardy's younger self both is and is not him, now, in the moment of writing the poem. Tangible and intangible works share this fate. This conclusion is what I now wish to tease out. It is what links conservation and scholarly editing.

\section{[BLANK LINE — SECTION BREAK]}

I invite readers to observe the naive or first-time editor at work. Let us say that the editor is male. He is editing a play of Shakespeare's. He finds the first textual difference between two copies of the same early edition, the result of stop-press printing. And then he finds differences between two early editions. He is aware that his publisher requires him to come up with a single reading text, not multiple ones. Let us say that he, as an experienced reader and a good literary critic, prefers one variant reading to the other because, say, it nicely completes the line as a perfect iambic pentameter. He accepts the missing syllable into his reading text and the line now scans. He has judged the textual variants aesthetically, according to poetic form. So far, so good.

His problem starts, however, when he strikes the second one, and then the third until, somewhat aghast at the Pandora's box he has opened, he finds there are some hundreds of them. Will his aesthetic sense that he has privileged in his first decision hold him in good stead throughout? Unless he is another Dr Johnson it will not. ${ }^{5}$ It is not his taste that readers have come to the edition to engage with. So he will soon be slipping and sliding as he tries to justify accepting this variant reading from the other edition, but not those other few on the same page.

To avoid this fate he brings bibliographic method to bear. He engages in very close study of the type and the flat-bed printing and gathering of sheets in these early seventeenth-century editions. What is odd about the typesetting? Why is it cramped here but loose there? Why is the same word spelled in different ways? Why, in these early editions, do some characters exit the stage before they have made their entrance? ${ }^{6}$ Because Shakespeare's original manuscripts are not extant our editor tries to detect the sequence of typesetting stints and the habits of spelling of the compositors, in this period before English spelling had become regular. To the extent that he can do it, he may be able to discount those habits so as to reveal some original features of Shakespeare's lost manuscript.

Our editor still has to assess the larger changes in wording among the early editions and extant copies. In doing so, he appeals continually to the evidence their variant versions reveal of

\footnotetext{
4 Brand 1997.

5 Samuel Johnson famously edited the works of Shakespeare in 1765.

6 Standard textbooks for postgraduate-level textual studies classes provide the answers, e.g. Keleman 2009, Greetham 1992. We have to imagine our first-time editor as having embarked on a steep learning curve here.
} 
how they were transmitted from manuscript to stage to print, and which parties might have affected this passage. By these means and others, bibliography and stage history rationally limit his aesthetic preferences. But he is in no doubt about his aim, which is to approximate as nearly as he can the state of the text as it left the author's hands. Therein lies its identity, he believes, its textual authenticity.

The methodology and the nascent theory that I have been describing correspond to the situation up until the $1980 \mathrm{~s}$. A single reading text that would most truly present the work was the assumed requirement. Publishers wanted it, general readers wanted it, stage directors and interpreting literary critics wanted it so they could get on with their different jobs more reliably. The work was assumed to be an ideal object hovering behind the early editions. Its text could, in theory at least, be approximated more closely and reliably than before because of the more or less scientific bibliographic methods brought to bear on revealing and analysing the textual variation.

But then in the 1980s the tide suddenly shifted, not just in editorial theory but in musicology, archaeological theory and ultimately in building and fine-art conservation. Was it obvious any longer that say, faced with the ruin of a magnificent building like the Parthenon, one would automatically aim, if one were given the chance, to restore it to its original form or originating moment? What of its two-and-a-half thousand years of worship, adaptation, military occupation and other change since? Was the evidence of those moments to be automatically effaced in favour of the original one? In the literary sphere, was it obvious any longer that the Shakespeare editor should efface, rather than preserve and editorially prefer, the evidence of those stage practices that had likely led to alteration in the manuscript sources of the widely variant early editions? And why exactly was Shakespeare-as-author the authenticating source rather than contemporaneous stage practice itself? His so-called Bad Quartos, thought by previous editors to have been cobbled together for sale by actors anxious to make a few shillings, had been treated with suspicion as likely to be confusing and misleading. But if these memorial reconstructions were closer to the stagings that the actors had actually appeared in, were they not a better report of that stage practice? Would it not be better to reprint them, errors and all, rather than continue to draw on the good Quartos and the famous First Folio in an eclectic mixture as had been the editorial norm?

This summary shows that the source of authenticity that the editor or conservator might appeal to in making decisions was shifting. So was the nature of the work's identity, which was no longer considered a reflection of some ideal. This was inevitable once the audience or the readership or the viewership was found to be not just relevant to, but actually constitutive of, the work. The Rembrandt painting or the Greek vase or the Shakespeare play was not identical with the object on the wall, or in the museum, or on stage, or as reported in this copy of Shakespeare's First Folio. Rather there was, in each case as well, a transaction, some equivalent of a speech-act perhaps, or a phenomenological realisation of the work on the part of the viewer or reader. That involvement formed part of the life of the work across time. This was additional to the work's history of early composition or design or making, its revision and production, and then its history of editorial or conservatorial interventions, all of which formed part of, as they also informed, that 
reception history. Works were always already in process. To think of them as a stabilisable product, unquestioned in their objecthood, was to misrepresent their conditioned existence. That, in summary, was the breakthrough, or breakout, that we saw amongst the theorists and the more radical practitioners in the late 1980s and 1990s, the ongoing effects of which we have been working our way through until this day.

The new realisation, ironically enough, echoed Ruskin's in 1849. He had railed against the nineteenth-century vogue of restoring the medieval churches in England:

[T] he word restoration ... means the most total destruction which a building can suffer ... a destruction with false description of the thing destroyed [i.e. that it is literally a restoration]. . - [l]t is impossible, as impossible as to raise the dead, to restore anything that has ever been great or beautiful in architecture ... [T] hat spirit which is given only by the hand and eye of the workman, can never be recalled... Do not then let us talk of restoration. The thing is a Lie from beginning to end. ${ }^{7}$

Of the buildings, he went on to declare: 'We have no right whatever to touch them. They are not ours. They belong partly to those who built them, and partly to all the generations of mankind who are to follow us. The dead still have their right in them.' The walls 'that have long been washed by the passing waves of humanity' only gradually acquire their living value - what he called 'that golden stain of time'. 8

To detach the work from its idealist grounding in the absent architect-author is therefore not necessarily to remove the basis of its identity. To think of the building or monument as a work unfolding over time rather than a static three-dimensional object is to recognise that its meanings are not fully determined in advance by builder or architect. They are also assigned by those who come into contact with the object. Semiotic appeals to meaning will be embedded in conventions of reading architecture, in the functions of buildings within broader circulating discourses, and they will be assigned variously and change over time. In other words, the building-as-work does not stay identical with itself.

Conservators' new acceptance of the authority of history cast further doubt over the old aesthetic ground for decision-making and the longstanding assumption about the objectivity of the work. ${ }^{9}$ These two bedfellows, long in uneasy alliance with one another, were now granted their divorce.

But there remained - there remains - a problem. If the grounds of identity of works are expanded, if every stage of a work's history is to be valued, if every generation's rights in the work are to be respected, if every adaptation of it serves as historical evidence of that work-in-process,

\footnotetext{
7 Ruskin 1910, 353-8.

8 Ruskin 1910, 358, 339, 340.

${ }^{9}$ See, for instance, the discussion of the restoration of the country house Uppark, in chap. 3 of Eggert 2009.
} 
then what ground does the editor-conservator now have for changing anything? A hundred years after the restorations Ruskin was protesting, and that Hardy was also unhappy with, Victorian additions to the medieval churches now take their place in the long history of adaptation of those same buildings. They were originally an irruptive response to the building's history but who would remove them now? 10

So also in literary studies. Scholarly editors realised that, for instance, the version of D. H. Lawrence's novel Sons and Lovers that nearly everyone from the 1960s until the 1980s read at school or university was actually an abridgement by a gifted publisher's editor, Edward Garnett. The young Lawrence, grateful the abridgement had been done for him so that the novel could be published and he could be paid, revised the proofs of the abridgement. Generations of readers who had engaged with it had their right in the abridgement they had read, and legions of literary critics wrote impressive and sensitised essays on the abridgement, assuming it to be the whole thing. Yet surely there should be grounds for restoring the version he originally wrote, for insisting on its primacy? ${ }^{11}$

Therein lay the new dilemma, which is still with us today. What firm ground can editors or conservators appeal to, if they believe in their heart of hearts that this thing needs altering? In their decision-making they do not want to be convicted of inconsistency. If they flip-flop as they make their hundreds of decisions about the words and punctuation of the new reading text or about cleaning these passages but not those in a darkened or damaged painting, their readers and viewers will be ill-served since they will not know how to read what the editors and conservators have done. The edition-as-work or the object-as-work will have become illegible. A more general model of the work is clearly needed, one that will acknowledge what has been learnt since the 1980s and that will, coherently, afford scope and justification for what conservators and editors feel the need to do now.

To achieve this, I have argued elsewhere ${ }^{12}$ that we first need to distinguish, more firmly than the old idealist and objectivist assumptions required us to do, between the material form and the meanings it acquires - in the literary context, between the dimensions of document and text. Document and text are forever locked together: each needs the other to secure its linked but different identity. They are in a negative dialectical relationship, one that unfolds over time. There can be no text without document, but paper and ink do not become, for readers, a document, until they begin to raise meaning from it. Once acknowledge the meanings (the textual dimension) as relevant to the editorial purview, then the viewer-reader who realises those meanings becomes, ineluctably, unavoidably, part of the equation. Similarly, if the act of conservation is intended to benefit visitors or viewers it cannot be considered only as an act of homage to its maker, or as being in the service of some ideal conception of the object.

10 See Pevsner 1969 and 1976.

11 See Baron and Baron 1992 for their solution in the Cambridge University Press Works of D. H Lawrence series.

12 Eggert 2009. 
I use the term 'object' but 'work' would be better, for it is the work-model that matters here. In my own field I have come to think of scholarly editions as embodied arguments about the constitution of the literary work. That is to say, editions are arguments in respect of something (typically original manuscripts or early editions carrying versions of the work) aimed at some contemporary audience. Editorial interventions in the texts of those versions are normally done with great pains, and within a tradition that renders them legible. They are done for a purpose. A new or altered material object is created - the new edition - and it takes up its place in the long history of the work. The scholarly edition cannot, as we may mistakenly assume it does, stand in some Olympian position above that history or outside of that history. It cannot, since it is subject to the same negative dialectic as every other edition. The new edition, aimed at an audience, enables the work to proceed into future decades only, editors hope, in a better-informed way than before.

The peculiar privilege and responsibility that editors and conservators share is to influence the terms of that transaction both through alteration and through curatorial or editorial explanation. Based on thorough research, a new edition or a new conservation brings new information from the work's history of documentary-textual or material-textual interchanges to bear. The conservator or editor proposes a new constitution for the work. The proposed argument must be able to withstand the usually disciplinary tests, with their many sharp edges. Reviewers and commentators soon tell us if we get it wrong. And there is always the chance of a latter-day Ruskin or James Beck or John Kidd laying in wait just around the corner. As we work he is, we fear, already breathing down our necks. ${ }^{13}$

When the conservator alters the fine-arts or decorative object, the alteration may not be fully reversible, even if that is the hope. Historic-building conservation is always in that predicament since the safety and other needs of modern visitors have literally to be built into the conservation. Adjustments may later be made, but there is no going back to a moment that has passed. I think of these forms of conservation as more heroic than mine. As a scholarly editor I aim to alter, for the better, the terms and conditions under which the literary work is encountered: I aim to extend its fruitful life by so doing. I do this in the knowledge that, whatever the shortcomings of my edition, at least I will not have altered the original manuscripts, typescripts, proofs or early rare editions upon which I draw, or at least, if I have done so, only in microscopic ways. This distinction between conservation and scholarly editing must be acknowledged of course; but it does not alter the fundamental parallel between them.

They share a need for a model of the work to which both may appeal in justifying their interventions into its material condition or linguistic text. That model needs to acknowledge the ongoing life of the work, which in turn requires an acknowledgement of the role of readers and viewers - even passers-by, as Ruskin says - in it. They realise - that is, they make real - the

\footnotetext{
13 See Beck 1993 for his campaign against the recent 'restoration' of the Sistine Chapel; see Kidd 1995 for his attack on Hans Walter Gabler's synoptic-text edition of James Joyce's Ulysses and Gabler 1996 for his reply.
} 
meanings of the work; and those realisations shift over time. It is into that essentially semiotic process of meaning-making that editors and conservators may justifiably intervene. Therefore we need a model of the work that embraces semiotics, that is, works as signs.

To understand works as signs, I believe that it is to C. S. Peirce's semiotics that conservators and editors can most profitably go because this Pragmatist philosopher, writing around the turn of the twentieth century, gets us outside the subject-object binary. I cannot pursue Peirce's account further here for the matter is too complex except to say he gives us a fresh account of the meaning of a thing over time: of its unrolling semiosis. ${ }^{14}$ Editors and conservators take part in this process. By their argued intervention they adjust the relation between material object and meaning.

This awareness of meaning-making is, to invoke Hardy's poem, their moment of selfunseeing now seen. Participating in the work in this agented way, rather than imagining themselves as enjoying an Olympian view above it, editors and conservators take on an ethical obligation to explain what they have done, to leave the viewer or reader in no doubt that what they now offer or present is not the so-called 'work itself'. They cannot offer this since there is no such thing; that concept is far too vulnerable to survive their sceptical gaze. But the work in its newly conserved state or edited version, understood as such, can and does defensibly emerge. Professional intervention to create it therefore must be legible via one means or another if viewers or readers are to understand what they are looking at or reading, and where they now stand in relation to it.

What then is the work? Borrowing from Immanuel Kant, I prefer to see the work not as the object itself or as a transcendent ideal implied by it but only as a regulative idea. 15 Under the name of the work we perform our readings and then, as privileged professionals, give them material form. We should do this according to a coherent argument and using our highest skills. These arguments are interventions into an existing climate of opinion. We address an always already existing concern to preserve the lifeline to the past that material objects, whether buildings, paintings or books, afford us. They exist in our embodied world, which feels smaller and has less chronological reach, affords us less footing, if they are destroyed or damaged. We share this concern with potential viewers or readers. The edition or the conservation carries the work forth in embodied form into this shared human world. That is why the edition-as-argument or the conservation-as-argument always matters. It is also why an ethics attends the acts of conservation and editing. We must be honest about what we do and claim. We may think of ourselves as standing outside the life of the work but in truth we cannot help but edit or conserve within it, take our part in its ongoing life.

14 The meaning of the sign, as Peirce portrayed it, is a developing thing. Semiosis is diachronic in his scheme (taking place over time), not synchronic, not the effect of a structuralist system, say of language, at any one moment. The sign functions, according to Peirce, by calling out an interpretant, that is, a meaning that may itself stand as a sign to some later interpretant. Things may take on this relational function of the sign. Thus semiosis, according to Peirce, must be understood as an unrolling process over time. See further Eggert 2009, chap. 10.

15 Guyer 2000. 
Thus the conservation or the edition will never escape the contexts of its performance. They will forever inflect the meanings the material object or document acquires through our interventions. We should not despair at this conclusion. Works have lives: all being well, those lives are the conserved object's passport into the future and they are ours into the past. That passport is not a constant for works do not stand still. In his own way Hardy registered this over a hundred years ago, and in the simplest and most telling of ways. He embraced the discomforting paradox with which we still struggle today. ${ }^{16}$

16 A first version of this chapter was given in a debate with Salvador Muñoz Viñas entitled 'Conservation and the Future' at Bard Graduate College for the Decorative Arts, New York on 31 March 2015. An expanded version entitled 'The Present, the Past and the Material Object: Digital Editions and Digital Archives' was subsequently presented as the inaugural lecture for the Martin J. Svaglic Endowed Chair in Textual Studies, Loyola University, Chicago on 14 October 2015. 
Bibliography

\section{Baron and Baron 1992}

Helen Baron and Carl Baron (eds.), D. H. Lawrence, Sons and lovers, Cambridge 1992.

\section{Beck 1993}

James Beck with Michael Daley, Art restoration. The culture, the business and the scandal, New York 1993.

\section{Brand 1994}

Stewart Brand, How buildings learn. What happens after they're built, New York \& London 1994.

\section{Dorset Chronicle 1824-1857}

Dorset County Chronicle, Dorchester, England 1824-1857.

\section{Eggert 2009}

Paul Eggert, Securing the past: Conservation in art, architecture and literature, Cambridge 2009.

\section{Gabler 1984}

Hans Walter Gabler, (ed.), James Joyce, Ulysses. A critical and synoptic edition, New York 1984, 3 vols.

\section{Gabler 1990}

Hans Walter Gabler, 'A response to John Kidd, "Errors of execution in the 1984 Ulysses"' Studies in the Novel, 22 (1990), 250-6.

\section{Greetham 1992}

David Greetham, Textual scholarship: An introduction, New York 1992.

\section{Guyer 2000}

Paul Guyer, (ed.), Immanuel Kant, Critique of the power of judgment (Paul Guyer and Eric Matthews, translators), 1790, Cambridge 2000. 


\section{Hardy 1902}

Thomas Hardy, Poems of the past and the present, London \& New York 1902.

\section{Hardy 1906}

Thomas Hardy, 'Memories of Church Restoration', 1906, in Harold Orel, (ed.), Thomas Hardy's Personal Writings, London \& Melbourne 1967, 203-217.

\section{Hardy 1927}

Thomas Hardy, 'The Ancient Cottages of England', 1927, in Harold Orel, (ed.), Thomas Hardy's Personal Writings, London \& Melbourne 1967, 233-235.

\section{Hutchins 1774}

John Hutchins, History and antiquities of the County of Dorset, London 1774, 2 vols.

\section{Hynes 1982}

Samuel Hynes, (ed.), The complete works of Thomas Hardy, Oxford 1982, 2 vols.

\section{Johnson 1765}

Samuel Johnson and George Steevens, (eds.), The plays of William Shakespeare, London 1765.

\section{Keleman 2009}

Erick Keleman, Textual editing and criticism: An introduction, New York 2009.

\section{Kidd 1988}

John Kidd, 'An inquiry into Ulysses. The corrected text', Papers of the Bibliographical Society of America 82 (1988), 411-584.

\section{Millgate 2004}

Michael Millgate, Thomas Hardy. A biography revisited, Oxford 2004. 
p. 16

\section{Pevsner 1969}

Nikolaus Pevsner, Ruskin and Viollet-le-Duc. Englishness and Frenchness in the appreciation of Gothic architecture, London 1969.

\section{Pevsner 1976}

Nikolaus Pevsner, Foreword to Stephan Tschudi-Madsen, Restoration and anti-restoration. A study in English restoration philosophy, Oslo 1976, 7-8.

\section{Pugin 1836}

Augustus W. N. Pugin, Contrasts, or, a parallel between the noble edifices of the fourteenth and fifteenth centuries and similar buildings of the present day, shewing the present decay of taste, London 1836.

\section{Pugin 1843}

Augustus W. N. Pugin, An apology for the revival of Christian architecture in England, London 1843.

\section{Ruskin 1910}

John Ruskin, 'The lamp of memory', in Seven lamps of architecture, 1849, 2nd edn 1880: London 1910.

\section{Viollet-le-Duc 1854-1868}

Eugène-Emmanuel Viollet-le-Duc, Dictionnaire raisonné de l'architecture francaise du XIe au XVIe siècle, Paris $1854-1868,10$ vols. 